
change

\title{
REDD+ policy networks: exploring actors and power structures in an emerging policy domain
}

\author{
Maria Brockhaus $^{1}$, Monica Di Gregorio $^{2}$ and Rachel Carmenta ${ }^{1}$
}

\begin{abstract}
Policy making is often neither rational nor solution-oriented, but driven by negotiations of interests of multiple actors that increasingly tend to take place in policy networks. Such policy networks integrate societal actors beyond the state, which all aim, to different degrees, at influencing ongoing policy processes and outcomes. Reducing Emissions from Deforestation and Forest Degradation (REDD+) can be considered as such an emerging policy domain, in which actors cooperate and conflict in network structures, build coalitions and try to control information and finance flows relevant for REDD+ decision making. This special feature is the result of an extensive comparative research effort to investigate national level REDD+ policy processes and emerging policy networks. This unique collection of seven country cases and a comparative study provides evidence on how power, coalitions, and different interactions among actors in policy networks enable the transformational change required for an effective, efficient, and equitable national REDD+ design. However, as we will see in most of the cases, where the dominant coalitions fail to tackle the drivers of deforestation and forest degradation, they also hinder such major policy reforms required for REDD+. The aim of this editorial serves four purposes: first, we provide an argument about "why" policy network analysis is highly relevant to the study of REDD+ policy processes; second, we explain "how" policy network analysis is used in this special feature to investigate policy processes in this domain; and third, we explore the "so what?" or how a policy network lens helps us understand the political opportunities and challenges for REDD+. Finally, we provide an outlook for the relevance and future research design of policy network analysis when applied to REDD+ and to policy network structures more broadly.
\end{abstract}

Key Words: agency; climate change; comparative analysis; discourse coalitions; policy network analysis; power; REDD+; SNA; transformational change

\section{INTRODUCTION}

Policy processes are inherently linked to power struggles, where policy making is driven by political disputes and interest competition rather than being a rational, solution-oriented process (Mayntz 1993, 2001). This becomes particularly visible in complex, multiactor, multisector, and multilevel policy processes, typical of environmental policy arenas. Here, negotiation of interests often takes place in emerging policy networks that integrate societal actors beyond the state, each aiming at influencing ongoing policy processes and outcomes.

In recent years, the analysis of policy networks, by which we mean the patterns of interactions and resource interdependencies between policy actors (Smith 1997), gained increased attention by scholars of environmental governance (Bulkeley 2000, Weible and Sabatier 2005, Sandström and Carlsson 2008, Fawcett and Daugbjerg 2012, Gale 2013). In policy networks, power, understood as the ability to influence policy outcomes (Arts 2003), is exercised, in large part, through different forms of interactions among a variety of policy actors (Daugbjerg 1998, Bulkeley 2000, Weible and Sabatier 2005, McClurg and Lazer 2014). Although today there is an increased understanding of the role of interactions, e.g., the exchange of information or financial resources, and policy network approaches are becoming more common, few policy network analyses have employed a comparative design to investigate policy processes (Knoke et al. 1996, Kriesi et al. 2006, Broadbent 2010, Broadbent and Vaughter 2014), in particular in developing countries.
This special feature is the result of an extensive comparative research effort to investigate national level policy processes and emerging policy networks around the forest-related climate change mitigation mechanism, known as Reducing Emissions from Deforestation and Forest Degradation (REDD+) in seven countries. This collection of seven country cases and a comparative study provides evidence about how power, coalitions, and different interactions among policy actors shape national REDD+ policies. Despite the variety of network related issues addressed in this special feature, all papers presented use a shared analytical lens and build on a common research methods design, contributing to fill the research gap for more systematic policy network research (Knoke et al. 1996, Kriesi et al. 2006, Ingold and Fischer 2014). Such an approach provides increased explanatory power of the individual case studies and allows for comparative analysis of policy networks.

The aim of this editorial serves four purposes: first, we provide an argument for "why" policy network analysis is highly relevant to the study of REDD+ policy processes; second, we explain "how" policy network analysis is used in this special feature to investigate policy processes in this domain; and third, we explore the "so what?," i.e., how a policy network lens helps us to understand the political opportunities and challenges associated with developing an effective, efficient, and equitable national REDD+ policy design (Angelsen and Wetz-Kanounnikoff 2008, Angelsen 2010). Finally, in an outlook section we draw some implications on the main findings from the papers of this special feature for the relevance and future research design of policy network analysis.

${ }^{1}$ Center for International Forestry Research, ${ }^{2}$ University of Leeds, Sustainability Research Institute 


\section{THE "WHY" OF POLICY NETWORK ANALYSIS ON REDD+}

REDD+ became part of the international climate change negotiation framework at the 13th Conference of the Parties (COP 13) of the United Nations Framework Convention on Climate Change (UNFCCC) in Bali in 2007. Since then a number of tropical forest countries have been engaged in the design and implementation of a national REDD+ architecture as part of what was then considered a cost-efficient response to the problem of climate change (Stern 2007). In order to achieve effective emission reductions, REDD+ will require transformational change, e.g., incentives for major policy reforms in various sectors of the economy that drive deforestation and forest degradation (Kanninen et al. 2007, Angelsen and McNeill 2012). A variety of policy actors, including government agencies, domestic and international NGOs and civil society organizations, "green" business, research and intergovernmental organizations engage in realizing such changes in domestic policy arenas. At the same time, some interest groups are trying to maintain existing structures that fuel deforestation and forest degradation by seeking political support and building coalitions to realize their economic interests (Ross 2001, Nepstad et al. 2013).

National REDD+ policy progress has so far been slower than expected and uncertainty on global and national policy directions, conflicting interests, real and perceived tensions between REDD+ and economic development objectives, and considerations about distribution of costs and benefits have been identified as some of the major challenges (Angelsen and McNeill 2012, Luttrell et al. 2013, Korhonen-Kurki et al. 2014). In the absence of obvious short-term win-win outcomes for all, at the national level such tensions emerge especially during policy negotiations about the details of the national REDD+ strategies (Brockhaus and Angelsen 2012, Brockhaus and Di Gregorio 2014). To understand what hinders or enables the transformational change required for realizing effective, efficient, and equitable REDD+ strategies it is important that we understand the processes that underlie such challenges.

Increasingly, research has adopted the lens of policy networks to investigate complex policy domains linked to social-ecological systems and environmental policy problems such as climate change and forest governance (Bulkeley 2000, Gallemore and Munroe 2013, Gale and Cadman 2014). Some of the reasons for these developments are explored below, with specific reference to the REDD+ policy domain. A policy network approach can help to investigate some key determinants of policy making in this domain. Among other issues, it provides a conceptual lens to:

1. Investigate in detail features of policy processes in multiactor policy domains

2. Explore how resource exchange, and pooling of resources, is used as a basis for political negotiation

3. Understand how policy actors exercise power and influence through interactions in policy processes

4. Analyze the form and role of policy coalitions in influencing policy outcomes
Multiactor policy domains

A policy network approach provides a way to integrate and investigate in detail policy actor systems that are broader than just formal institutional structures of the state (Kenis and Raab 2008). It is therefore a concept that operates at the meso-level ${ }^{[1]}$, focusing on interactions among organizations (Rhodes 1997, Evans 2001). For example, realizing emission reduction through REDD+ requires policy action and reforms in a large number of sectors including forestry, agriculture, and infrastructure development, which affect different business interests, smallholders, local communities, and government plans (Di Gregorio et al. 2012). It also requires planning, participation, and compliance by actors operating at different jurisdictional levels (Pacheco et al. 2011, Korhonen-Kurki et al. 2012). With the expansion of the role of business, civil society, and international actors in national policy making, diverse forms of consultation have become institutionalized and policy decisions are no longer the exclusive domain of state actors. This is, for example, reflected in the decision making around the operationalization of REDD+ safeguards (Roe et al. 2013, Arhin 2014, UNFCCC 2014).

Resource exchange for political negotiation in policy networks In these emerging policy domains, interactions of different actors and interests are used to mobilize and pool resources and support, in order to shape policy outcomes and realize their interests (Kenis and Schneider 1991). Material and nonmaterial interdependencies reveal how organizations bargain with one another to affect policy outcomes (Laumann and Knoke 1987). In fact, social action can be understood as a negotiating process in which actors interact, exchange resources, and use them to realize their interests (Hanf and Scharf 1978, Coleman 1990). These resource exchanges are used to consolidate existing policy positions and maintain established power structures as well as facilitate policy changes (Friedland and Alford 1991, Börzel 1997, Marsh and Smith 2000). Financial resources for REDD+ come predominantly from international sources (multilateral and bilateral) and are channelled through national government, NGOs, and civil society sectors to a variety of actors at different levels. Other resources are provided in-kind, such as scientific knowledge and expertise. Given the high level of technical knowledge required to set up the institutional structures, e.g., forest inventories and monitoring systems, to support REDD+ implementation, governments rely in part on nonstate actors including international and national research and civil society organizations to mobilize such expertise.

\section{Exerting power and influence through interactions}

To understand progress in national REDD+ policy making, such as why, for example, substantial policy reforms in the sectors driving deforestation are slow to be realized, we can start by investigating the structure of power that underlies national REDD+ policy networks. Policy networks "reflect past power distributions and conflicts," yet, at the same time they "shape present political outcomes" (Marsh and Smith 2000:6). Policy networks, therefore, reveal the institutionalization of power relations of actors that are part of the network and the constraints formed by the broader political context. By analyzing the form that policy networks take, and the relations between different actors and their positions in these policy networks, we can gain a deeper understanding of policy actors' roles and power in a particular policy domain and can infer possible effects on policy 
outcomes (Knoke 1990, Marsh and Rhodes 1992, Knoke et al. 1996, Broadbent and Vaughter 2014).

For example, the papers in this special feature: identify whether REDD+ policy networks are dominated by a few very influential actors, as opposed to representing an inclusive and diffuse distribution of power; identify those actors that facilitate, control, or restrict information flows within and among coalitions; investigate who these central actors are and whether they support business-as-usual or policy reforms; these are some of the ways in which the policy network lens can gain deeper understanding of policy processes. Marsh and Rhodes (1992:267-268, emphasis in the original, as cited in Hudson and Lowe 2009:161) argue that policy networks are "central to understand resistance to [policy] changes and the ways in which political institutions and practices adapt 'because' policy networks are political structures which filter or mediate the change." Such resistance to change becomes obvious in countries where drivers of deforestation are primarily due to large-scale industrial operations, such as palm oil development in Indonesia, or cattle ranching in Brazil. In such contexts we would expect to find resistance to REDD+-related actions aimed at reforming these sectors. Such high levels of political resistance was, for example, evident in the policy debates accompanying the establishment of the moratorium on exploitation of natural forest and peatland in Indonesia in 2011, and the revisions of the forestry code in Brazil in 2013 (May et al. 2011, Di Gregorio et al. 2012, Indrarto et al. 2012).

Policy coalitions for change: ideas and interactions Policy network approaches can identify policy coalitions, and how these influence policy change (Matti and Sandström 2011). In this sense, networks are not just the reflection of institutional structures and are not static (Marsh and Smith 2000). For example, policy actors recruit like-minded allies to help form powerful coalitions, they argue with one another to influence the ideas of other actors, and bargain and negotiate to break up networks and underlying power structures (Marsh and Smith 2000, Mische and Pattison 2000, Weible and Sabatier 2005, Ingram et al. 2014). Policy change is most often driven by coalitions of actors that share similar beliefs, values, and policy objectives (Österblom and Bodin 2012). To translate their ideas into public policy, coalitions have to coordinate and interact (Sabatier and Jenkins-Smith 1993). Combining the analysis of relations between actors with information about their ideas and beliefs provides a useful way to identify political coalitions and assess the power and dominance of these coalitions, and their position in policy networks (Matti and Sandström 2011, Leifeld and Haunss 2012). Where powerful coalitions are advocating for policy reforms, such reforms are more likely to occur (Fischer 2013). Within the REDD+ policy domain this would translate, for example, into more consistent and effective progress in the development of REDD+ strategies and changes in policy directions from business-as-usual to tackling the major drivers of deforestation and forest degradation (Brockhaus and Angelsen 2012, Brockhaus et al. 2013, Babon et al. 2014).

In summary, the policy network lens can be useful to characterize single organizations that are part of the policy domain, while at the same time providing a complete overview of network structures. The combination of detail and breadth allows us to understand meso-level policy processes, from which one can develop targeted policy recommendations for effective policy changes for REDD+ that take into account the structural constraints and opportunities, as well as the potential of policy actors to facilitate policy change. However, it is important to note that not all of the actors forming the policy network are elected nor necessarily adhering to any institutional requirements, and so the issues of transparency and legitimacy become evident.

\section{THE "HOW" OF POLICY NETWORK ANALYSIS IN REDD+}

The policy research component of the Global Comparative Study on REDD+ led by the Center for International Forestry Research, uses policy network analysis as one of its central theoretical and methodological approaches (Brockhaus and Di Gregorio 2012). By analyzing policy networks to investigate actors relevant in REDD+ policy processes, their relations, and the structural conditions in the specific REDD+ policy arenas, we aim to understand the political structures that support or hamper transformational change and REDD+ policy progress. We explore how resistance can be overcome to build a carbon effective, cost efficient, and equitable REDD+ regime.

This special feature presents some of the results obtained from data collected over one thousand interview hours, focusing on the national level policy network analyses for seven countries (Brazil, Cameroon, Indonesia, Nepal, Papua New Guinea, Tanzania, and Vietnam), one study at the subnational level in Indonesia, and a comparative study. Although each study in this special feature followed the same research design, each one focuses on distinct questions around national REDD+ policy processes and uses different techniques and social network measures. Countries were purposefully selected based on their relevance for and early engagement with REDD+, the presence of pilot projects, and the presence of established partnerships to conduct the research. At the time of data collection (2010-2012), all countries included were in the phase of institutional and pilot project set-up, i.e., REDD+ Readiness Phase, or moving into the REDD+ implementation of policies and measures (Meridian Institute 2009).

\section{Boundary setting and policy events}

The first step in the policy network analysis was to identify the policy actors that are part of the national REDD+ policy domains. An initial identification of domain actors was based on two earlier research outputs, i.e., a country profile and the analyses of media articles on REDD+, and country researchers' knowledge (Brockhaus and Di Gregorio 2012, Brockhaus et al. 2012, Di Gregorio et al. 2013). The complete list of actors was then validated by a panel or five to six experts in each country. To set the boundaries, only "core actors" were asked for interviews. We identified core actors using the criteria of relevance as: an organization that defines itself, and that is perceived by others, as a part of the national REDD+ policy domain. The criteria of relevance suggests that other members in the policy domain need to take into account a specific actor when they make decisions, even if the first is not directly involved in decision making.

For each country, a full roster of all relevant organizations (i.e., actors) was drawn up, and these organizations were then contacted to take part in a survey. We recorded respondents' perceptions of the influence of listed policy actors, a measure 
called "perceived influence" or "reputation power" (Knoke et al. 1996, Kriesi and Jegen 2001) and of five types of interactions: exchanges of financial (and in-kind material) resources, general and scientific information, collaborative ties, and conflictual interactions.

Research teams also identified up to five key national REDD+ policy events. We defined a policy event as "a critical, temporally located decision point in a collective decision-making sequence that must occur in order for a policy option to be finally selected" (Laumann and Knoke 1987:251). This includes both policy proposals being discussed and actual major policy decisions taken in the relative country. The list of policy events was used in the survey to ask whether policy actors participated in these events, in which role, and the extent to which they were satisfied with the outcomes (Fillieule and Jiménez 2003).

Some limitations of the methods need to be highlighted. First, the policy network analysis conducted investigates network structures at one point in time, the time of the survey. Policy processes are, however, dynamic processes. Although policy networks analysis suggests that network structures tend to be stable over time, this has also been an area of contention (Marsh and Smith 2000). In particular, "new" policy domains, such as REDD+, are likely to be more dynamic than long established policy domains. We need therefore to interpret the results of the policy analysis within the temporal context of the survey. Second, the response rate of the survey varied from $56 \%$ to $100 \%$, which means that it was difficult in most countries to obtain information for all policy actors identified. Such missing information can impact social network measures, in particular when very relevant actors did not participate in the survey (Burt 1987, Wasserman and Faust 1994, Borgatti and Molina 2003). These limitations are recognized and to reduce the bias of missing responses the papers include the observed incoming ties of nonrespondents when measuring reputational power (Costenbader and Valente 2003). In the comparative studies we assess the extent of missing data in all the case studies (see Appendix in Brockhaus and Di Gregorio 2014).

\section{Survey tools and data collection}

Each country team administered an organizational survey and, where possible, a semistructured interview. Both the survey and interview were undertaken with a senior representative of each organization that was involved in or had good knowledge of national REDD+ policy processes.

\section{Organizational survey: stances, networks, and protest events}

The survey elicited responses in a fixed choice format, including questions about: (1) the position of organizations on key REDD+ issues; (2) identification of the actors that they considered particularly influential in the REDD+ policy domain; (3) the five different types of interactions with other actors in the policy domain, i.e., exchange of information, providing and receiving funds and in-kind resources, scientific information, collaboration, and disagreement; (4) participation in five previously selected REDD+ policy events and protest events; and (5) characteristics and resources of organizations (see Appendix 1).

To elicit information on the position of organizations on key REDD+ issues, position statements (or stances) were formulated to facilitate a response either in agreement or disagreement (non- neutral statements). Position statements covered key issues debated in international and national REDD+ circles, REDD+ specific elements such as sustainable forest management and enhancement of carbon stocks, the delivery of REDD+ cobenefits, e.g., poverty reduction and biodiversity, governance issues, prominent REDD+ policy challenges, and the role of science in policy, for a total of 35 stances.

\section{Semistructured interviews}

The semistructured interviews were based on a guide of openended questions, which encouraged respondents to talk in some depth about four main topics. They were asked to discuss: (1) the interest of the organization in the REDD+ policy domain; (2) their perception on what the main policy challenges and opportunities are in REDD+ policy making, with particular attention given to governance aspects; (3) the dynamics and effectiveness of the consultation processes linked to the development on the national REDD+ strategy; and (4) their assessment of national REDD+ policy processes (see Appendix 2). The interviews were recorded and transcribed for analysis. Analysis of transcripts was done with open coding techniques using the qualitative analysis computer software package Nvivo (Mayring 2004, QSR 2012).

\section{Network analysis}

Policy network analysis builds on quantitative social network analysis techniques, a method used to investigate social structures (Börzel 1997, Wasserman and Faust 1994). There are three main levels of analysis: (1) network measures investigate overall structural features of a network, (2) group level measures investigate features relating to the composition and characteristics of subnetworks formed by groups of actors, and (3) actor level measures assess the positions and roles of specific actors within a network (Scott 2000, Prell 2012).

Network level measures such as cohesion, density, or centralization characterize the network as a whole. They can indicate a number of different tendencies in networks. For example, highly centralized policy networks, such as one centered on a specific government agency, may facilitate coordination, but are also likely to be highly exclusive, marginalizing dissenting forces (Diani and McAdam 2003, Sandström and Carlsson 2008, Bodin and Crona 2009). Networks with low cohesion characterize networks where subgroups are disconnected. They indicate fragmentation, obstacles to collective action, and likely low levels of consensus (Granovetter 1973, Borgatti and Foster 2003, Bodin and Crona 2009). Network level measures are particularly useful to compare across the different network relations within a policy domain, e.g., REDD+. For example comparing between information and collaboration networks may reveal particular obstacles that hamper another network relation (Heimeriks et al. 2003, Weible and Sabatier 2005, Saunders 2007, Bushley 2014, Gebara et al. 2014).

Actor level measures, e.g., betweeness and in-degree centrality, etc., "zoom in" and investigate positions and roles of specific policy actors in a network. As an example, high levels of centrality of an actor, i.e., in-degree, which indicates the total number of ties of an actor, or betweeness, which measures how often an actor appears on shortest paths between other actors in the network, or high brokerage scores, referring to actors that act as mediators between two other actors in a network, characterize actors that 
are able to exert influence over others in the network, control resource flows between other actors, and might be better situated to, e.g., access information or other resources (Gould and Fernandez 1989, Degenne and Forsé 1999, Scott 2000, Burt 2004). These measures were applied in most of the papers in this special feature (Babon et al. 2014, Bushley 2014, Dkamela et al. 2014, Gebara et al. 2014, Moeliono et al. 2014, Rantala and Di Gregorio 2014). Actor level measures are also used to investigate associations and causal relationships between relational and other variables. Causality can be investigated using approaches such as quadratic assignment procedure and Exponential Random Graph Models, as applied in two of the papers in this special feature, to model organizational collaboration (Lusher et al. 2012, Gallemore et al. 2014, Moeliono et al. 2014).

There are many different ways to analyze subgroup structures in networks. Blockmodeling techniques rely on structural equivalence, grouping actors that occupy similar structural positions in a network, meaning that they are connected in the same ways to related actors (Wasserman and Faust 1994, Doreian et al. 2004). Combined with measures of influence of actors, blockmodeling can help to determine actor groups that dominate and those that are more peripheral (followers or marginalized) in a policy domain (Kriesi and Jegen 2001). This technique was applied in the global comparative paper in this special feature to compare networking patterns across countries and investigate how different political structures impact REDD+ policy development in the seven countries (Brockhaus and Di Gregorio 2014).

In addition, combining network measures with other attributes, nonrelational information about actors, and more detailed qualitative information from interviews provides a way to explore networking in more depth, including, for example, to investigate the meaning of relations, e.g., based on shared ideas or beliefs (White et al. 2007, Crossley 2010). Such analysis underpins the papers in this special feature that investigate homophily in policy coalitions (Moeliono et al. 2014, Rantala and Di Gregorio 2014).

Finally, social network analysis can be used to explore affiliation networks, which investigate the relations between two different sets of categories, e.g., actors and policy events (Borgatti and Everett 1997, Carrington et al. 2005). This technique is used to identify levels of inclusion in policy events in the Vietnam case study (Pham et al. 2014).

\section{THE "SO WHAT?" OF POLICY NETWORK ANALYSIS ON REDD+: EVIDENCE FROM SEVEN COUNTRIES}

The case studies in this special feature reflect a range of policy research questions that can be explored through a policy network lens. Key issues that were analyzed center around information flows, policy coalitions and discourses, and power in national REDD+ policy domains. We draw on these studies to illustrate how using a policy network analysis as a point of departure helps us to understand the political opportunities and challenges for transformational change in REDD+.

\section{Information flows and information holes}

Information network measures can generate insights into the extent to which organizations are working together in the REDD+ policy arena. Gallemore et al. (2014) demonstrate this by examining the extent of collaboration and information sharing between organizations in Central Kalimantan, Indonesia. They identify "discursive divides" that constrain the cross-scale collaboration necessary for effective REDD+ policy development. Moeliono et al. (2014) utilize information exchange measures to identify potential barriers to transformational change. They find that influential government agencies are fairly isolated from other actors and do not seem to be interested in seeking outside sources of information. The absence of brokers between state and nonstate actors leads to a fragmented REDD+ policy arena characterized by top-down decisions, which is unlikely to leverage the adaptive management required for REDD+.

\section{Policy beliefs, discourses, and coalitions}

In national REDD+ arenas, as in other policy domains, it is primarily policy coalitions, as opposed to individual organizations, that drive resistance to, as well as the direction of, policy change. In particular, combining evidence from interactions among actors with their ideas and beliefs can help reveal why some policy domains resist change and others facilitate policy reforms.

Drawing on the advocacy coalition framework, Babon et al. (2014) examine potential pathways to transformational change in Papua New Guinea. They argue that members of different coalitions form "coalitions of convenience." Organizations may defect from one coalition to another, bringing their influence and resources with them. Their findings suggest that, despite the early presence of high-profile REDD+ policy entrepreneurs and the government's pro-REDD+ position at the international level, the most powerful coalition of actors in the domestic policy sphere continue to defend existing institutional structures that support business as usual, often under the guise of agricultural development. Complementing social network with discourse analysis, Rantala and Di Gregorio (2014) show how in Tanzania there are two main opposing policy coalitions that support distinct directions for REDD+. They analyze the discourses of these coalitions and show how the content of National REDD+ Strategy reflects the bargaining power of these two opposing coalitions.

\section{Power and influence: driving change?}

The investigation of how influence is exerted through interactions lies at the center of the policy network concept. In this special feature "power" is conceptualized as the ability of actors to influence forestry and land-use decisions such that the outcomes of these decision processes serve their interests (Arts 2003, Arts and Van Tatenhove 2004, Biermann 2010, Krott et al. 2013). It is operationalized mainly as the way in which actors use reputational power and their position in material and immaterial resources exchange networks to exert influence (Marsh and Rhodes 1992, Fischer et al. 2007, Heaney 2014). Power over the REDD+ policy process has many different expressions. As an example, the degree of concentration of power in particular actors can either reflect the autonomy of the nation state from the interests driving deforestation and forest degradation, the extent of national versus international ownership over reform processes, or the level of inclusiveness of policy processes. The case studies from Cameroon (Dkamela et al. 2014), Vietnam (Pham et al. 2014), Nepal (Bushley 2014), Brazil (Gebara et al. 2014), and the comparative paper (Brockhaus and Di Gregorio 2014) all investigate issues related to distribution of power. 
In Cameroon, the international actors are central in controlling and facilitating information flows across organisations, whereas state actors are less involved and domestic civil society organizations are peripheral. The limited presence of domestic actors among the leading organizations indicates that national ownership of the REDD+ process is low (Dkamela et al. 2014). The lack of domestic leadership in REDD+, low levels of inclusiveness, and the absence of a substantive national REDD+ coalition mirror similar weaknesses experienced in earlier forestry law reform processes, and reveal path-dependent power structures.

The analysis of participation in decision making in key policy events reveals a very different reality in Vietnam (Pham et al. 2014). Government agencies dominate REDD+ policy making, leaving limited political space for nonstate actors such as NGOs and civil society organizations, yet, even within these circumstances nonstate actors have been able to present alternative policy options. This suggests that the REDD+ consultation processes have had some effect, yet there is the need for more inclusive and accountable policy processes.

Measures of reputational power, information exchanges, and collaborative ties between REDD+ actors are used to assess whether REDD+ is threatening to recentralize forest management in Nepal (Bushley 2014). Here, REDD+ policy is largely shaped by the interactions among a triad of government agencies, peak civil society organizations, and international actors, while the nonforest related government agencies, the private sector, and community organizations represent weaker sections of society remain in the periphery of the REDD+ policy network. Such features indicate that REDD+ might be reversing some of the gains of decades of decentralized community forestry in Nepal. In the Brazil case study, Gebara et al. (2014) combine evidence from social network and qualitative analysis to examine the polarization of views on key REDD+ issues and the extent of coordination among government agencies, NGOs, and the private sector. They use a variety of centrality and brokerage measures from different network relations to identify who is shaping the policy design of the national strategy. They find that while government agencies and national NGOs are the most central actors in the REDD+ arena, coordination roles are limited to a few international donors and domestic NGOs. Polarization and lack of coordination across sectors and with the private sector are identified as the main constraints to transformational change.

Power structures in a country affect its progress in national REDD+ policy making, yet the broader political context and the stage of REDD+ policy development shape these power structures in turn. The comparative paper identifies the different power structures in the REDD+ domain in the seven countries based on two dimensions: the level of distribution of power and the dominant type of interaction, i.e., either cooperation or conflict. This analytical lens is used to map how different power structures impact the progress of REDD+ decision-making processes (Brockhaus and Di Gregorio 2014).

\section{OUTLOOK}

We draw on the papers herein to provide an outlook for the relevance and future design of policy network analysis when applied to REDD+, but also when applied to policy networks more broadly. This special feature provides a unique collection of individual case studies of national REDD+ policy networks that use a common methodology and are complemented by a comparative analysis. The reader can gain insights of countries' individual and shared opportunities and obstacles for promoting a national REDD+ agenda that is carbon-effective, cost-efficient, and equitable, while delivering cobenefits. All case studies show to higher or lesser degrees how national REDD+ policy arenas are still dominated by powerful business-as-usual interests, reflected in some countries' reluctance to undertake the larger policy reforms that would enable the required change and effectiveness in tackling the often underlying causes of deforestation and forest degradation. The individual papers in this special feature also provide insights and possible ways forward to overcome these challenges. In doing so, the case studies use a range of analytical angles and perspectives that policy network analysis allows for, in a context of highly diverse political regimes and governance structures.

The studies provide evidence of how power structures that are embedded in interactions among a variety of different policy actors with varying interests and ideas contribute to REDD+ progress. The power of agency remains somewhat underexplored in the policy network literature. However, its application to the investigation of policy coalitions provides some insights into agency and drivers of policy change, and powerful forces that hinder such change, as shown in most of the REDD+ policy domains investigated in this special feature. The position of powerful actors in policy interactions, the distribution of power, and the features of the dominant policy coalitions in national REDD+ contribute to explain REDD+ outcomes, or, as most case studies indicate, the lack of achieving these. However, these aspects shed less light into how changes in power structures occur and why and how REDD+ policy networks change over time. Policy network analysis has been criticized for focusing primarily on structural and stable features of policy domains (Börzel 1997). To help understand how past processes have impacted current policy networks structures and are likely to impact future developments, the case studies in this special feature use a combination of networking data and qualitative data on policy processes. However, the use and advances in longitudinal analysis of policy networks, where network data are observed at different points in time (Snijders et al. 2007, Ingold and Fischer 2014) provides a way to further investigate policy network change over time.

Finally, the comparative analysis of policy networks in different countries presents a number of methodological challenges, because social network analysis is best suited to compare different relations among the same actors as opposed to networks formed by different actors altogether (Knoke et al. 1996). To advance the value of policy network analysis for understanding policy processes and outcomes, and to strengthen its explanatory power as theory and method of investigation of environmental governance, longitudinal analysis, a stronger recognition of the role of agency in policy networks, and additional efforts for comparative analyses are required.

${ }^{[1]}$ Meso-level policy analysis focuses on "how policies come to be made, who puts them on the policy agenda, and the structure of institutional arrangement in which policy is defined and eventually implemented" (Hudson and Lowe 2009:11, emphasis in the original). 
Responses to this article can be read online at: http://www.ecologyandsociety.org/issues/responses. php/7098

\section{Acknowledgments:}

This research is part of the policy component of CIFOR's Global Comparative Study on REDD+ (http://www. forestsclimatechange. org/global-comparative-study-on-redd.html). The methods applied in this study build partially on research undertaken by the Comparing Climate Change Policy Networks programme (http:// compon.org), led by Jeffrey Broadbent and funded by the National Science Foundation. The authors would like to express their deep gratitude to our partners and the individual country teams in the global comparative study, without whose work in the research countries this special issue would not have been possible. Sofi Mardiah, Efrian Muharrom, Cynthia Maharani, Bimo Dwisatrio, Januarti Tjajadi, Christine Wairata, and Imogen Badgery-Parker played highly valuable roles in research support and editing. We are very grateful to Örjan Bodin for his insightful comments on the manuscript. Funding for CIFOR's research was provided by the Norwegian Agency for Development Cooperation, the Australian Agency for International Development, the UK Department for International Development, and the European Commission.

\section{LITERATURE CITED}

Angelsen, A. 2010. The 3 REDD 'I's. Journal of Forest Economics 16:253-256. http://dx.doi.org/10.1016/j.jfe.2010.10.001

Angelsen, A., and D. McNeill. 2012. The evolution of REDD+: A political economy framework. Pages 31-48 in A. Angelsen, M. Brockhaus, W. D. Sunderlin, and L. Verchot, editors. Analysing REDD+: challenges and choices. Center for International Forestry Research, Bogor, Indonesia.

Angelsen, A., and S. Wetz-Kanounnikoff. 2008. What are the key design issues for REDD and the criteria for assessing options? Pages 11-21 in A. Angelsen, editor. Moving ahead with REDD: issues, options and implications. Center for International Forestry Research, Bogor, Indonesia.

Arhin, A. A. 2014. Safeguards and dangerguards: a framework for unpacking the black box of safeguards for REDD+. Forest Policy and Economics 45:24-31. http://dx.doi.org/10.1016/j. forpol.2014.05.003

Arts, B. 2003. Non-state actors in global governance: three faces of power. Max-Planck-Gesellschaft, Munich, Germany.

Arts, B., and J. Van Tatenhove. 2004. Policy and power: a conceptual framework between the 'old' and 'new' policy idioms. Policy Sciences 37:339-356. http://dx.doi.org/10.1007/s11077-005-0156-9

Babon, A., D. Mcintyre, G. Y. Gowae, C. Gallemore, R. Carmenta, M. Di Gregorio, and M. Brockhaus. 2014. Advocacy coalitions, REDD+, and forest governance in Papua New Guinea: How likely is transformational change? Ecology and Society 19(3): 16. http://dx.doi.org/10.5751/ES-06486-190316

Biermann, F. 2010. Beyond the intergovernmental regime: Recent trends in global carbon governance. Current Opinion in
Environmental Sustainability 2:284-288. http://dx.doi.org/10.1016/ j.cosust.2010.05.002

Bodin, Ö., and B. I. Crona. 2009. The role of social networks in natural resource governance: What relational patterns make a difference? Global Environmental Change 19:366-374. http://dx. doi.org/10.1016/j.gloenvcha.2009.05.002

Borgatti, S. P., and M. G. Everett. 1997. Network analysis of 2mode data. Social Networks 19:243-269. http://dx.doi. org/10.1016/S0378-8733(96)00301-2

Borgatti, S. P., and P. C. Foster. 2003. The network paradigm in organizational research: a review and typology. Journal of Management 29:991-1013. http://dx.doi.org/10.1016/S0149-2063 (03)00087-4

Borgatti, S. P., and J. L. Molina. 2003. Ethical and strategic issues in organizational social network analysis. Journal of Applied Behavioral Science 39:337-349. http://dx.doi.org/10.1177/00218$\underline{86303258111}$

Börzel, T. A. 1997. What's so special about policy networks? An exploration of the concept and its usefulness in studying European governance. European Integration online Papers (EIoP) 1(16). [online] URL: http://eiop.or.at/eiop/texte/1997-016a.htm

Broadbent, J. 2010. Science and climate change policy making: a comparative network perspective. Pages 187-214 in A. Sumi, K. Fukushi, and A. Hiramatusu, editors. Adaptation and mitigation strategies for climate change. Springer, New York, New York, USA. http://dx.doi.org/10.1007/978-4-431-99798-6 13

Broadbent, J., and P. Vaughter. 2014. Inter-disciplinary analysis of climate change and society: a network approach. Pages 203-228 in M. J. Manfredo, J. J. Vaske, A. Rechkemmer, E. A. Duke, editors. Understanding society and natural resources. Springer, Dordrecht, The Netherlands. http://dx.doi.org/10.1007/978-94-$\underline{017-8959-210}$

Brockhaus, M., and A. Angelsen. 2012. Seeing REDD+ through 4Is: a political economy framework. Pages 15-30 in A. Angelsen, M. Brockhaus, W. D. Sunderlin, and L. V. Verchot, editors. Analysing REDD+: challenges and choices. Center for International Forestry Research, Bogor, Indonesia.

Brockhaus, M., and M. Di Gregorio. 2012. A brief overview: component 1 on national REDD+ policies and processes. CIFOR Infobrief 13. Center for International Forestry Research, Bogor, Indonesia.

Brockhaus, M., and M. Di Gregorio. 2014. National REDD+ policy networks: from cooperation to conflict. Ecology and Society 19(4): 14. http://dx.doi.org/10.5751/ES-06643-190414

Brockhaus, M., M. Di Gregorio, and S. Mardiah. 2013. Governing the design of national REDD+: an analysis of the power of agency. Forest Policy and Economics. http://dx.doi. org/10.1016/j.forpol.2013.07.003

Brockhaus, M., M. Di Gregorio, and S. Wertz-Kanounnikoff. 2012. Guide for country profiles: global comparative study on REDD (GCS-REDD) component 1 on national REDD+ policies and processes. Center for International Forestry Research, Bogor, Indonesia. 
Bulkeley, H. 2000. Discourse coalitions and the Australian climate change policy network. Environment and Planning C: Government and Policy 18:727-748. http://dx.doi.org/10.1068/c9905j

Burt, R. S. 1987. A note on missing network data in the general social survey. Social Networks 9:63-73. http://dx.doi. org/10.1016/0378-8733(87)90018-9

Burt, R. S. 2004. Structural holes and good ideas. American Journal of Sociology 110:349-399. http://dx.doi.org/10.1086/421787

Bushley, B. R. 2014. REDD+ policy making in Nepal: toward state-centric, polycentric, or market-oriented governance? Ecology and Society 19(3): 34. http://dx.doi.org/10.5751/ ES-06853-190334

Carrington, P. J., J. Scott, and S. Wasserman, editors. 2005. Models and methods in social network analysis. Cambridge University Press, Cambridge, New York, New York, USA. http://dx.doi. org/10.1017/CBO9780511811395

Coleman, J. S. 1990. Foundations of social theory. Harvard University Press, Cambridge, Massachusetts, USA.

Costenbader, E., and T. W. Valente. 2003. The stability of centrality measures when networks are sampled. Social Networks 25:283-307. http://dx.doi.org/10.1016/S0378-8733(03)00012-1

Crossley, N. 2010. The social world of the network: combining quantitative and qualitative elements in social network analysis. Sociologica 1. http://dx.doi.org/10.2383/32049

Daugbjerg, C. 1998. Policy networks under pressure: pollution control, policy reform and the power of farmers. Ashgate, Brookfield, Vermont, USA.

Degenne, A., and M. Forsé. 1999. Introducing social networks. Sage, Thousand Oaks, California, USA.

Diani, M., and D. McAdam, editors. 2003. Social movements and networks: relational approaches to collective action. Oxford University Press, Oxford, UK. http://dx.doi.org/10.1093/019925$\underline{1789.001 .0001}$

Di Gregorio, M., M. Brockhaus, T. Cronin, and E. Muharrom. 2012. Politics and power in national REDD+ policy processes. Pages 69-90 in A. Angelsen, M. Brockhaus, W. D. Sunderlin, and L. Verchot, editors. Analysing REDD+: challenges and choices. Center for International Forestry Research, Bogor, Indonesia.

Di Gregorio, M., S. Price, C. Saunders, and M. Brockhaus. 2013. Code book for the analysis of media frames in articles on REDD. Center for International Forestry Research, Bogor, Indonesia.

Dkamela, G. P., M. Brockhaus, F. Kengoum Djiegni, J. Schure, and S. Assembe Mvondo. 2014. Lessons for REDD+ from Cameroon's past forestry law reform: a political economy analysis Ecology and Society 19(3): 30. http://dx.doi.org/10.5751/ ES-06839-190330

Doreian, P., V. Batagelj, and A. Ferligoj. 2004. Generalized blockmodeling. Cambridge University Press, New York, New York, USA. http://dx.doi.org/10.1017/CBO9780511584176

Evans, M. 2001. Understanding dialectics in policy network analysis. Political Studies 49:542-550. http://dx.doi. org/10.1111/1467-9248.00326
Fawcett, P. and C. Daugbjerg. 2012. Explaining governance outcomes: epistemology, network governance and policy network analysis. Political Studies Review 10:195-207. http://dx.doi. org/10.1111/j.1478-9302.2012.00257.x

Fillieule, O., and M. Jiménez. 2003. Appendix A: the methodology of protest event analysis and the media politics of reporting environmental protest events. Pages 258-279 in C. Rootes, editor. Environmental protest in Western Europe. Oxford University Press, Oxford, UK.

Fischer, F., G. J. Miller, M. S. Sidney, editors. 2007. Handbook of public policy analysis: theory, politics, and methods CRC, Taylor \& Francis, Boca Raton, Florida, USA.

Fischer, M. 2013. Policy network structures, institutional context, and policy change. COMPASSS Working Paper Series 2013-73.

Friedland, R., and R. R. Alford. 1991. Bringing society back in: symbols, practices, and institutional contradictions. Pages 232-263 in W. W. Powell and P. J. Dimaggio, editors. The new institutionalism in organizational analysis. University of Chicago Press, Chicago, Illinois, USA.

Gale, F. 2013. When interests trump institutions: Tasmania's forest policy network and the Bell Bay pulp mill. Environmental Politics 22:274-292. http://dx.doi.org/10.1080/09644016.2012.683150

Gale, F., and T. Cadman. 2014. Whose norms prevail? Policy networks, international organizations and "sustainable forest management." Society and Natural Resources 27:170-184. http:// dx.doi.org/10.1080/08941920.2013.840875

Gallemore, C., and D. K. Munroe. 2013. Centralization in the global avoided deforestation collaboration network. Global Environmental Change 23:1199-1210. http://dx.doi.org/10.1016/ j.gloenvcha.2013.04.004

Gallemore, C. T., R. Dini Prasti H., and M. Moeliono. 2014. Discursive barriers and cross-scale forest governance in Central Kalimantan, Indonesia. Ecology and Society 19(2): 18. http://dx. doi.org/10.5751/ES-06418-190218

Gebara, M. F., L. Fatorelli, P. May, and S. Zhang. 2014. REDD+ policy networks in Brazil: constraints and opportunities for successful policy making. Ecology and Society 19(3): 53. http:// dx.doi.org/10.5751/ES-06744-190353

Gould, R. V., and R. M. Fernandez. 1989. Structures of mediation: a formal approach to brokerage in transaction networks. Sociological Methodology 19:89-126. http://dx.doi. org/10.2307/270949

Granovetter, M. S. 1973. The strength of weak ties. American Journal of Sociology 78:1360-1380. http://dx.doi.org/10.1086/225469

Hanf, K., and F. W. Scharf. 1978. Interorganizational policy making: limits to coordination and central control. Sage, London, UK.

Heaney, M. T. 2014. Multiplex networks and interest group influence reputation: an exponential random graph model. Social Networks 36:66-81. http://dx.doi.org/10.1016/j.socnet.2012.11.003

Heimeriks, G., M. Hörlesberger, and P. Van Den Besselaar. 2003. Mapping communication and collaboration in heterogeneous research networks. Scientometrics 58:391-413. http://dx.doi. org/10.1023/A:1026296812830 
Hudson, J., and S. Lowe. 2009. Understanding the policy process: analysing welfare policy and practice. Policy Press, Portland, Oregon, USA.

Indrarto, G. B., P. Murharjanti, J. Khatarina, I. Pulungan, F. Ivalerina, J. Rahman, M. N. Prana, I. A. P. Resosudarmo, and E. Muharrom. 2012. The context of REDD+ in Indonesia. Working Paper. Center for International Forestry Research, Bogor, Indonesia.

Ingold, K., and M. Fischer. 2014. Drivers of collaboration to mitigate climate change: an illustration of Swiss climate policy over 15 years. Global Environmental Change 24:88-98. http://dx. doi.org/10.1016/j.gloenvcha.2013.11.021

Ingram, M., H. Ingram, and R. Lejano. 2014. What's the story? Creating and sustaining environmental networks. Environmental Politics 1-19. http://dx.doi.org/10.1080/09644016.2014.919717

Kanninen, M., D. Murdiyarso, F. Seymour, A. Angelsen, S. Wunder, and L. German. 2007. Do trees grow on money?: the implications of deforestation research for policies to promote $R E D D$. Center for International Forestry Research, Bogor, Indonesia.

Kenis, P., and J. Raab. 2008. Politiknetzwerke als Governanceform: Versuch einer Bestandsaufnahme und Neuausrichtung der Diskussion. Pages 132-148 in G. F. Schuppert and M. Zürn, editors. Governance in einer sich wandelnden Welt. VS Verlag für Sozialwissenschaften, Wiesbaden, Germany.

Kenis, P., and V. Schneider. 1991. Policy networks and policy analysis: scrutinizing a new analytical toolbox. in B. Marin and R. Mayntz, editors. Policy networks: empirical evidence and theoretical considerations. Westview, Boulder, Colorado, USA.

Knoke, D. 1990. Political networks: the structural perspective. Cambridge University Press, Cambridge, UK. http://dx.doi. org/10.1017/CBO9780511527548

Knoke, D., F. U. Pappi, J. Broadbent, and Y. Tsujinaka. 1996. Comparing policy networks: labor politics in the US, Germany, and Japan. Cambridge University Press, Cambridge, UK. http://dx. doi.org/10.1017/CBO9781139174497

Korhonen-Kurki, K., M. Brockhaus, A. E. Duchelle, S. Atmadja, and T. T. Pham. 2012. Multiple levels and multiple challenges for REDD. Pages 91-110 in A. Angelsen, M. Brockhaus, W. D. Sunderlin, and L. V. Verchot, editors. Analysing REDD+: challenges and choices. Center for International Forestry Research, Bogor, Indonesia.

Korhonen-Kurki, K., J. Sehring, M. Brockhaus, and M. Di Gregorio. 2014. Enabling factors for establishing REDD+ in a context of weak governance. Climate Policy 14:167-186. http:// dx.doi.org/10.1080/14693062.2014.852022

Kriesi, H., S. Adam, and M. Jochum. 2006. Comparative analysis of policy networks in Western Europe. Journal of European Public Policy 13:341-361. http://dx.doi.org/10.1080/13501760500528803

Kriesi, H., and M. Jegen. 2001. The Swiss energy policy elite: the actor constellation of a policy domain in transition. European Journal of Political Research 39:251-287. http://dx.doi. org/10.1111/1475-6765.00577
Krott, M., A. Bader, C. Schusser, R. R. Devkota, A. Maryudi, L. Giessen, and H. Aurenhammer. 2013. Actor-centred power: the driving force in decentralised community based forest governance. Forest Policy and Economics, in press. http://dx.doi.org/10.1016/ j.forpol.2013.04.012

Laumann, E. O., and D. Knoke. 1987. The organizational state: social choice in national policy domains. University of Wisconsin Press, Madison, Wisconsin, USA.

Leifeld, P., and S. Haunss. 2012. Political discourse networks and the conflict over software patents in Europe. European Journal of Political Research 51:382-409. http://dx.doi.org/10.1111/ j.1475-6765.2011.02003.x

Lusher, D., J. Koskinen, and G. Robins. 2012. Exponential random graph models for socialnetworks: theory, methods, and applications. Cambridge University Press, Cambridge, UK. http://dx.doi. org/10.1017/CBO9780511894701

Luttrell, C., L. Loft, M. F. Gebara, D. Kweka, M. Brockhaus, A. Angelsen, and W. D. Sunderlin. 2013. Who should benefit from REDD+? Rationales and realities. Ecology and Society 18(4): 52. http://dx.doi.org/10.5751/ES-05834-180452

Marsh, D., and R. W. A. Rhodes. 1992. Policy networks in British Government. Clarendon, Oxford, UK. http://dx.doi.org/10.1093/ acprof:0so/9780198278528.001.0001

Marsh, D., and M. J. Smith. 2000. Understanding policy networks: towards a dialectical approach. Political Studies 48:4-21. http://dx.doi.org/10.1111/1467-9248.00247

Matti, S., and A. Sandström. 2011. The rationale determining advocacy coalitions: examining coordination networks and corresponding beliefs. Policy Studies Journal 39:385-410. http:// dx.doi.org/10.1111/j.1541-0072.2011.00414.X

May, P. H., B. Millikan, and M. F. Gebara 2011. The context of REDD+ in Brazil: drivers, agents, and institutions. Occasional Paper. Center for International Forestry Research, Bogor, Indonesia.

Mayntz, R. 1993. Policy-Netzwerke und die Logik von Verhandlungssystemen. Pages 39-56 in A. Héritier, editor. PolicyAnalyse: Kritik und Neuorientierung. Westdeutscher Verlag Oplanden, Opladen, Germany. http://dx.doi.org/10.1007/978-3-663-01473-7 2

Mayntz, R. 2001. Zur Selektivität der steuerungstheoretischen Perspektive. Pages 17-27 in H. P. Burth, and A. Görlitz, editors. Politische Steuerung in Theorie und Praxis. Nomos, Baden Baden, Germany.

Mayring, P. 2004. Qualitative content analysis. Pages 266-269 in U. Flick, E. Von Kardoff, and I. Steinke, editors. A companion to qualitative research. Sage, London, UK.

McClurg, S. D., and D. Lazer. 2014. Political networks. Social Networks 36:1-4. http://dx.doi.org/10.1016/j.socnet.2013.09.001

Meridian Institute. 2009. REDD+ institutional options assessment: developing and efficient, effective, and equitable institutional framework ofr REDD+ under the UNFCCC. C. Streck, L. Gomez-Echeverri, P. Gutman, C. Loisel, and J. Werksman. Meridian Institute, Washington, D.C., USA. 
Mische, A., and P. Pattison. 2000. Composing a civic arena: publics, projects, and social setting. Poetics 27:163-194. http://dx. doi.org/10.1016/S0304-422X(99)00024-8

Moeliono, M., C. Gallemore, L. Santoso, M. Brockhaus, and M. Di Gregorio. 2014. Information networks and power: confronting the "wicked problem" of REDD+ in Indonesia. Ecology and Society 19(2): 9. http://dx.doi.org/10.5751/ES-06300-190209

Nepstad, D. C., W. Boyd, C. M. Stickler, T. Bezerra, and A. A. Azevedo. 2013. Responding to climate change and the global land crisis: REDD+, market transformation and low-emissions rural development. Philosophical Transactions of the Royal Society B: Biological Sciences 368(1619). http://dx.doi.org/10.1098/rstb.2012.0167

Österblom, H., and Ö Bodin. 2012. Global cooperation among diverse organizations to reduce illegal fishing in the Southern Ocean. Conservation Biology 26:638-648. http://dx.doi. org/10.1111/j.1523-1739.2012.01850.x

Pacheco, P., M. Aguilar-Støen, J. Börner, A. Etter, L. Putzel, and M. D. C. V. Diaz. 2011. Landscape transformation in tropical Latin America: assessing trends and policy Implications for REDD+. Forests 2:1-29. http://dx. doi.org/10.3390/f2010001

Pham, T. T., M. Di Gregorio, R. Carmenta, M. Brockhaus, and D. N. Le. 2014. The REDD+ policy arena in Vietnam: participation of policy actors. Ecology and Society 19(2): 22. http://dx.doi.org/10.5751/ES-06389-190222

Prell, C. 2012. Social network analysis: history, theory and methodology. Sage, London, UK.

Qsr 2012. NVivo qualitative data analysis software, Version 10. QSR International Pty Ltd., Doncaster, Australia.

Rantala, S., and M. Di Gregorio. 2014. Multistakeholder environmental governance in action: REDD+ discourse coalitions in Tanzania. Ecology and Society 19(2): 66. http://dx. doi.org/10.5751/ES-06536-190266

Rhodes, R. A. W. 1997. Understanding governance: policy networks, governance, reflexivity and accountability. Open University Press, Buckingham, UK.

Roe, S., C. Streck, L. Pritchard, and J. Costenbader. 2013. Safeguards in REDD+ and forest carbon standards: a review of social, environmental and procedural concepts and application. Climate Focus, Amsterdam, The Netherlands.

Ross, M. L. 2001. Timber booms and institutional breakdown in Southeast Asia. Cambridge University Press, Cambridge, UK. http://dx.doi.org/10.1017/CBO9780511510359

Sabatier, P. A., and H. C. Jenkins-Smith, editors. 1993. Policy change an learning: an advocacy coalition approach. Westview, Boulder, Colorado, USA.

Sandström, A., and L. Carlsson. 2008. The performance of policy networks: the relation between network structure and network performance. Policy Studies Journal 36:497-524. http://dx.doi. org/10.1111/j.1541-0072.2008.00281.X

Saunders, C. 2007. Using social network analysis to explore social movements: a relational approach. Social Movement Studies 6:227-243. http://dx.doi.org/10.1080/14742830701777769
Scott, J. 2000. Social network analysis: a handbook. Sage, London, UK.

Smith, M. J. 1997. Policy networks. Pages 76-86 in M. Hill, editor. The policy process: a reader. Prentice Hall, London, UK.

Snijders, T. A. B., C. E. G. Steglich, and M. Schweinberger. 2007. Modeling the co-evolution of networks and behavior. Pages 41-71 in K. Van Montfort, J.. Oud, and A. Satorra, editors. Longitudinal models in the behavioral and related sciences. Lawrence Erlbaum Associates, Mahwah, New Jersey, USA.

Stern, N. 2007. The economics of climate change: the Stern review. Cambridge University Press, Cambridge, UK. http://dx.doi. org/10.1017/CBO9780511817434

United Nations Framework Convention on Climate Change (UNFCCC). 2014. Report of the conference of the parties on its nineteenth session: Addendum. Part two: Action taken by the Conference of the Parties at its nineteenth session. Warsaw, 11 to 23 November 2013. UNFCCC, Bonn, Germany.

Wasserman, S., and K. Faust. 1994. Social network analysis: methods and applications. Cambridge University Press, Cambridge, UK. http://dx.doi.org/10.1017/CBO9780511815478

Weible, C. M., and P. A. Sabatier. 2005. Comparing policy networks: marine protected areas in California. Policy Studies Journal 33:181-201. http://dx.doi.org/10.1111/j.1541-0072.2005.00101. $\underline{\mathrm{X}}$

White, H., J. Fuhse, M. Thiemann, and L. Buchholz. 2007. Networks and meaning: styles and switchings. Soziale Systeme 13:543-555. 


\section{SOCIAL ORGANIZATION OF THE NATIONAL REDD POLICY DOMAIN SURVEY TEMPLATE}

Interview Number:

Organization ID:

Name of Organization (core actor):

\{if the above is a sub-unit of bigger organization specify:\}

The above organizational actor is part of:

Name of main organization:

Name of organization's informant:

Informant's position within the organization:

Informant's Title:

Informant's Telephone:

Second Informant (IF ANY):

Informant's Title:

Informant's Telephone:

Interviewer:

Date:

Time:

Place:

NOTE: wording in \{ \} brackets is explanatory text aimed at the interviewer to highlight specific aspects of the survey. It is thought for internal use. 


\section{Organizational Efforts on REDD}

\section{Introduction}

This research project studies the positions and activities of organizations concerning issues related to Reduced Emissions from Deforestation and Degradation (REDD). There are many different opinions about this subject. We would like to talk with you today about the positions and activities of (ORG NAME) concerning these issues. Because interviews are being carried out with many organizations, we will follow an interview guide to make sure we cover all the questions. The name of the respondent will be kept confidential.

Question 1: Please indicate the amount of effort your organization typically devotes to each theme related to land use and REDD, using the six response categories to the right.

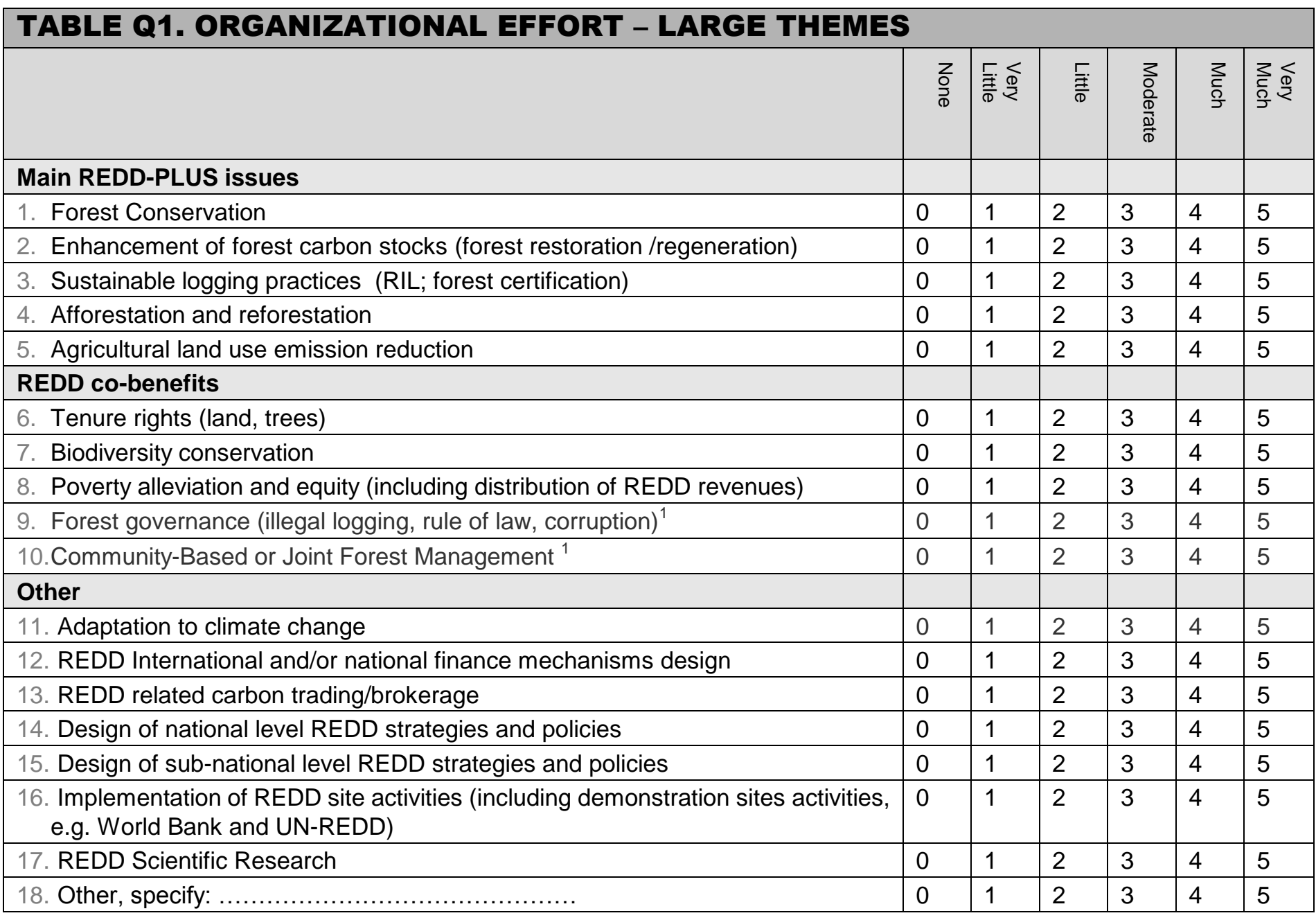

Question 2

Which theme in Table Q1 does your organization have the longest experience with ?

Question 3

Roughly, what percentage of its total work does (ORG NAME) devote specifically to REDD issues? $\%$

\footnotetext{
${ }^{1}$ Here intended as potential co-benefits (output of REDD schemes)
} 


\section{Organizational Stance on International and National REDD Issues}

\section{Question 4}

Next we want to talk about the stance or position of (ORG NAME) on important international and national issues regarding REDD. In Table Q4, these issues are stated in a one-sided manner to allow agreement or disagreement. Please circle the number that best reflects the level of agreement/disagreement of (ORG NAME)'s typical policy stance with the issue as stated. Please note that not all organizations are engaged with the vast variety of issues related to REDD. If you feel there is no specific or implied position of your organizations on one of the issues you can tick 'neither agree nor disagree'. If the topic is unknown to you and your organization please tick 'not known/no response'

NOTE: These response categories differ from the previous ones.

\{the choice 'not known/no response' should also be ticked in cases when the respondent does not know or does not respond\}

\section{TABLE Q4. ORGANIZATIONAL STANCE ON NATIONAL REDD ISSUES}

REDD: International issues:

1. REDD is an effective option for reducing green house gas emissions globally

2. REDD is a financially affordable way to mitigate climate change

3. REDD will assure fairness in the international distribution of environmental costs and benefits

4. REDD schemes should only be financed through funds

5. In the long-run REDD should be included in schemes to offset credits in compliance carbon markets

6. In the post-Kyoto regime the definition of forest should exclude monocultures

\section{REDD: General national issues:}

7. All REDD accounting and payments should go through the national governments

8. REDD benefits should reward large-scale industries/companies for reducing forest emissions

9. REDD should mainly reward local people for emission reduction activities

10.REDD schemes will exacerbate conflicts about forest land and forest resources

\section{REDD Co-Benefits:}

11. All REDD schemes aimed at reducing $\mathrm{CO}^{2}$ emissions should also require the realization of other key benefits like poverty reduction and biodiversity conservation

12. Improved recognition of local tenure rights is a pre-condition for effective and equitable implementation of REDD schemes

13. REDD schemes developed with the sole objectives to reduce $\mathrm{CO}^{2}$ emissions are likely to be in contrast with biodiversity conservation aims.

14. REDD schemes will be an important resource to reduce poverty

15. Without involvement of local people in their implementation, REDD projects are unlikely to be effective

\section{Governance of REDD:}

16. REDD schemes will provide incentives and resources to improve forest governance (e.g.illegal logging and rule of law)

17. Strengthened governance is a pre-condition for successful REDD schemes

18. REDD schemes will further weaken the limited administrative capacity of the state

\begin{tabular}{|c|c|c|c|c|c|}
\hline 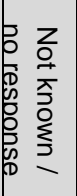 & 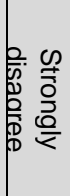 & 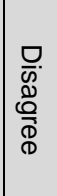 & 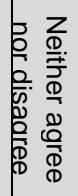 & 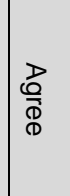 & 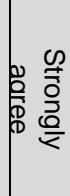 \\
\hline 0 & 4 & 0 & 0 & 4 & 5 \\
\hline 0 & 1 & $\frac{c}{2}$ & 3 & 4 & 5 \\
\hline 0 & 1 & 2 & 3 & 4 & 5 \\
\hline 0 & 1 & 2 & 3 & 4 & 5 \\
\hline 0 & 1 & 2 & 3 & 4 & 5 \\
\hline 0 & 1 & 2 & 3 & 4 & 5 \\
\hline 0 & 1 & 2 & 3 & 4 & 5 \\
\hline 0 & 1 & 2 & 3 & 4 & 5 \\
\hline 0 & 1 & 2 & 3 & 4 & 5 \\
\hline 0 & 1 & 2 & 3 & 4 & 5 \\
\hline 0 & 1 & 2 & 3 & 4 & 5 \\
\hline 0 & 1 & 2 & 3 & 4 & 5 \\
\hline 0 & 1 & 2 & 3 & 4 & 5 \\
\hline 0 & 1 & 2 & 3 & 4 & 5 \\
\hline 0 & 1 & 2 & 3 & 4 & 5 \\
\hline 0 & 1 & 2 & 3 & 4 & 5 \\
\hline 0 & 1 & 2 & 3 & 4 & 5 \\
\hline 0 & 1 & 2 & 3 & 4 & 5 \\
\hline
\end{tabular}




\begin{tabular}{|c|c|c|c|c|c|c|}
\hline & 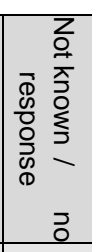 & 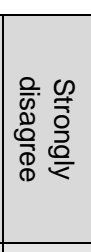 & 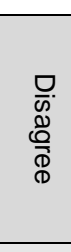 & 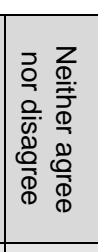 & 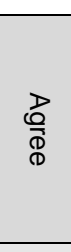 & 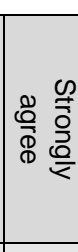 \\
\hline \multicolumn{7}{|l|}{ One of the main challenges for an effective REDD national strategy is ... } \\
\hline 19. ... lack of knowledge and awareness on REDD by relevant stakeholders & 0 & 1 & 2 & 3 & 4 & 5 \\
\hline $\begin{array}{l}\text { 20. ... achieving effective coordination between state agencies, the private sector, } \\
\text { and civil society }\end{array}$ & 0 & 1 & 2 & 3 & 4 & 5 \\
\hline $\begin{array}{l}21 . . . \text { the lack of technical expertise for monitoring carbon emissions and } \\
\text { sequestration }\end{array}$ & 0 & 1 & 2 & 3 & 4 & 5 \\
\hline 22. .... the effective clarification of tenure rights & 0 & 1 & 2 & 3 & 4 & 5 \\
\hline $\begin{array}{l}\text { 23. ... contradictions among laws and regulations in forestry, agriculture and other } \\
\text { sectors }\end{array}$ & 0 & 1 & 2 & 3 & 4 & 5 \\
\hline 24. ... social conflict and local resistance & 0 & 1 & 2 & 3 & 4 & 5 \\
\hline $\begin{array}{l}\text { 25. ... effectively addressing main drivers of deforestation without compromising } \\
\text { development objectives }\end{array}$ & 0 & 1 & 2 & 3 & 4 & 5 \\
\hline 26. ... achieving broad consensus on changes in existing land use plans & 0 & 1 & 2 & 3 & 4 & 5 \\
\hline 27. ... low capacity to enforce laws and regulations & 0 & 1 & 2 & 3 & 4 & 5 \\
\hline $\begin{array}{l}\text { 28.... negotiating with powerful special interests influencing the main drivers of } \\
\text { deforestation }\end{array}$ & 0 & 1 & 2 & 3 & 4 & 5 \\
\hline \multicolumn{7}{|l|}{ REDD and Science: } \\
\hline 29. Scientific experts are the best and final authority on REDD & 0 & 1 & 2 & 3 & 4 & 5 \\
\hline $\begin{array}{l}\text { 30. Scientific experts dominate the national REDD policy discussion, at the expense } \\
\text { of other relevant interests (e.g. business and civil society organizations) }\end{array}$ & 0 & 1 & 2 & 3 & 4 & 5 \\
\hline \multicolumn{7}{|l|}{ Technical REDD Aspects: } \\
\hline \multicolumn{7}{|l|}{$\begin{array}{l}\text { Below, are a few further stances with refer to very technical aspects of REDD. Not all } \\
\text { organizations involved in the REDD policy domain will be familiar or engaged with these } \\
\text { issues, which are usually only relevant for more scientifically specialized organizations. } \\
\text { If your organization is not familiar with these issues please tick '0' }\end{array}$} \\
\hline $\begin{array}{l}\text { 31. REDD schemes are also likely to help countries to cope or adapt to the impacts } \\
\text { of climate change }\end{array}$ & 0 & 1 & 2 & 3 & 4 & 5 \\
\hline $\begin{array}{l}\text { 32. REDD schemes should always require permission from local forest resource } \\
\text { users in the form of Free Prior and Informed Consent (FPIC) }\end{array}$ & 0 & 1 & 2 & 3 & 4 & 5 \\
\hline $\begin{array}{l}\text { 33. Forest conservation schemes, sustainable forest management and } \\
\text { enhancement of forest carbon stocks should all be eligible for REDD }\end{array}$ & 0 & 1 & 2 & 3 & 4 & 5 \\
\hline $\begin{array}{l}\text { 34. REDD mechanisms are unlikely to be effective in reducing national level } \\
\text { emissions because of difficulties in controlling leakage and in assuring the } \\
\text { additionality and permanence }\end{array}$ & 0 & 1 & 2 & 3 & 4 & 5 \\
\hline $\begin{array}{l}\text { 35. A national approach (for reference levels, MRV, rewards etc.) is necessary to } \\
\text { ensure effectiveness of REDD schemes (as compared to project-based approach) }\end{array}$ & 0 & 1 & 2 & 3 & 4 & 5 \\
\hline
\end{tabular}

\{Below is a space for any notes by the interviewer on the above section\} 


\section{Organizational Activities}

Question 5

Please look at Table 5 below. This is a list of organizational activities. Please indicate how much effort your organization devotes to each type of activity related to REDD, using the six response categories to the right.

\begin{tabular}{|l|l|l|l|l|l|l|}
\hline TABLE Q5. ORGANIZATIONAL ACTIVITIES ON REDD \\
\hline & None & $\begin{array}{l}\text { Very } \\
\text { Little }\end{array}$ & \multicolumn{1}{|l|}{$\begin{array}{l}\text { Little } \\
\text { erate }\end{array}$} & $\begin{array}{l}\text { Much } \\
\text { Much }\end{array}$ \\
\hline 1. Advocacy & 0 & 1 & 2 & 3 & 4 & 5 \\
\hline 2. Fund-raising & 0 & 1 & 2 & 3 & 4 & 5 \\
\hline $\begin{array}{l}\text { 3. Networking (facilitating coordination and/or information } \\
\text { flows between organizations) }\end{array}$ & 0 & 1 & 2 & 3 & 4 & 5 \\
\hline 4. Publications and education & 0 & 1 & 2 & 3 & 4 & 5 \\
\hline 5. Project implementation & 0 & 1 & 2 & 3 & 4 & 5 \\
\hline 6. Research & 0 & 1 & 2 & 3 & 4 & 5 \\
\hline $\begin{array}{l}\text { 7. Government policy advice (your organization does not } \\
\text { hold formal decision-making authority) }\end{array}$ & 0 & 1 & 2 & 3 & 4 & 5 \\
\hline $\begin{array}{l}\text { 8. Government policy formulation (your organization holds } \\
\text { formal decision-making authority) }\end{array}$ & 0 & 1 & 2 & 3 & 4 & 5 \\
\hline 9. Government policy implementation & 0 & 1 & 2 & 3 & 4 & 5 \\
\hline 10. Regulation of businesses & 0 & 1 & 2 & 3 & 4 & 5 \\
\hline 11. Carbon trading, brokering, investment advice & 0 & 1 & 2 & 3 & 4 & 5 \\
\hline 12. Changing public awareness and behaviour & 0 & 1 & 2 & 3 & 4 & 5 \\
\hline 13. Provide discussion forums & 0 & 1 & 2 & 3 & 4 & 5 \\
\hline 14. Other, specify: .................... & 0 & 1 & 2 & 3 & 4 & 5 \\
\hline
\end{tabular}




\section{Networking among Organizations}

\{This section investigates REDD policy networking activities. It identifies and traces different types of relations between organizations. Questions refer to the influence of other organizations, communication/exchange of information, sources of scientific information, organizations with opposing positions, and organizations with whom there is collaboration\}

Network questions introduction:

Now we want to ask about (ORG NAME)'s relations with other organizations and actors. Please answer each question by putting a tick by the relevant organizations from the following list. There is also space at the bottom for you to add important organizations/actors if they are not on the list.

Question N 1: \{lnfluence - subjective\}

Please indicate those organizations that stand out as especially influential on domestic REDD policies by putting a tick after the organizations' names.

Question N 2:\{Regular COMMUNICATION and INFORMATION EXCHANGE \}

Please indicate those organizations with which (ORGNAME) regularly or routinely discusses and exchanges information about national REDD policy matters?

Question N 3: \{RECEIVE expert scientific information about\}

Sometimes organizations need expert scientific information about REDD that can only be provided by other organizations or particular scientists. On which organizations does (ORGNAME) rely on to obtain reliable scientific information on REDD?

(if information is received from independent consultants not affiliated with any specific organizations, please add the name of the consultant at the bottom of the list and tick it)

Question N 4: \{GIVE FUNDS \}

To which organizations on List 1 has (ORGNAME) contributed substantial funds or other in-kind resources as payments and cost-sharing for services or goods, or for voluntary contributions including co-sponsoring of activities of common interest.

Question N 5: \{RECEIVE FUNDS \}

From which organizations has (ORGNAME) received substantial funds as payments for services or goods, or as other types of contributions including co-sponsoring of meetings and events?

Question N 6: \{OPPONENTS\}

With which organizations does (ORGNAME) often find itself disagreeing on REDD policy issues?

Question N 7: \{INFORMAL COALITIONS\}

With which other organizations does (ORG NAME) regularly collaborate concerning REDD related issues? 
LIST of Organizations: Answer sheet Network Section:

\begin{tabular}{|c|c|c|c|c|c|c|c|c|c|}
\hline & & & N1 & N2 & N3 & N4 & N5 & N6 & N7 \\
\hline $\begin{array}{l}\text { Govern } \\
\text { Departn }\end{array}$ & $\begin{array}{l}\text { ent, state a } \\
\text { ents, Agenc }\end{array}$ & $\begin{array}{l}\text { encies and expressly political organizations (Bureaus, } \\
\text { es, Government Research Institutes, Political Parties etc.): }\end{array}$ & & & & & & & \\
\hline org_id & Acronym & Full Name & & & & & & & \\
\hline 1 & & & & & & & & & \\
\hline 2 & & & & & & & & & \\
\hline 3 & & & & & & & & & \\
\hline$\ldots$ & & & & & & & & & \\
\hline & & & & & & & & & \\
\hline & & & & & & & & & \\
\hline & & & & & & & & & \\
\hline & & & & & & & & & \\
\hline & & & & & & & & & \\
\hline & & & & & & & & & \\
\hline $\begin{array}{l}\text { Nationa } \\
\text { Acaden }\end{array}$ & $\begin{array}{l}\text { Research II } \\
\text { c institutiol }\end{array}$ & titutes (Think Tanks, Independent advisory bodies, & & & & & & & \\
\hline & & & & & & & & & \\
\hline & & & & & & & & & \\
\hline & & & & & & & & & \\
\hline & & & & & & & & & \\
\hline & & & & & & & & & \\
\hline & & & & & & & & & \\
\hline & & & & & & & & & \\
\hline & & & & & & & & & \\
\hline & & & & & & & & & \\
\hline & & & & & & & & & \\
\hline $\begin{array}{l}\text { Nationa } \\
\text { Associ } \\
\& \text { Cons }\end{array}$ & $\begin{array}{l}\text { Business o } \\
\text { ions, Resea } \\
\text { Itants }\end{array}$ & $\begin{array}{l}\text { yanizations (Domestic):Business Associations, Trade } \\
\text { ch Institutes, Insurance, Banks, Investors, Single Businesses }\end{array}$ & & & & & & & \\
\hline & & & & & & & & & \\
\hline & & & & & & & & & \\
\hline & & & & & & & & & \\
\hline & & & & & & & & & \\
\hline & & & & & & & & & \\
\hline & & & & & & & & & \\
\hline & & & & & & & & & \\
\hline & & & & & & & & & \\
\hline & & & & & & & & & \\
\hline & & & & & & & & & \\
\hline Nation: & Profession & Associations (Foresters, ...) & & & & & & & \\
\hline & & & & & & & & & \\
\hline & & & & & & & & & \\
\hline & & & & & & & & & \\
\hline & & & & & & & & & \\
\hline & & & & & & & & & \\
\hline & & & & & & & & & \\
\hline
\end{tabular}




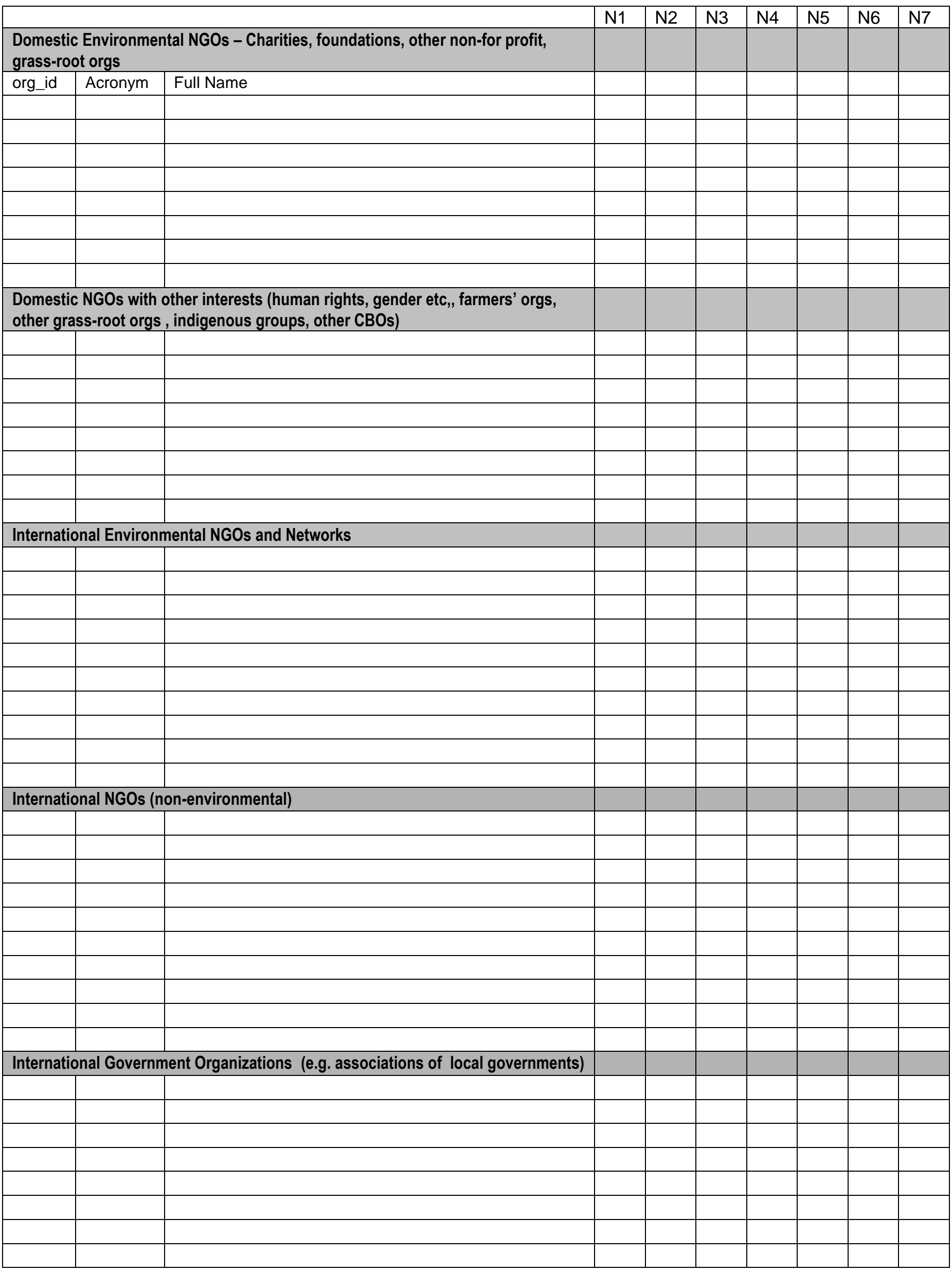




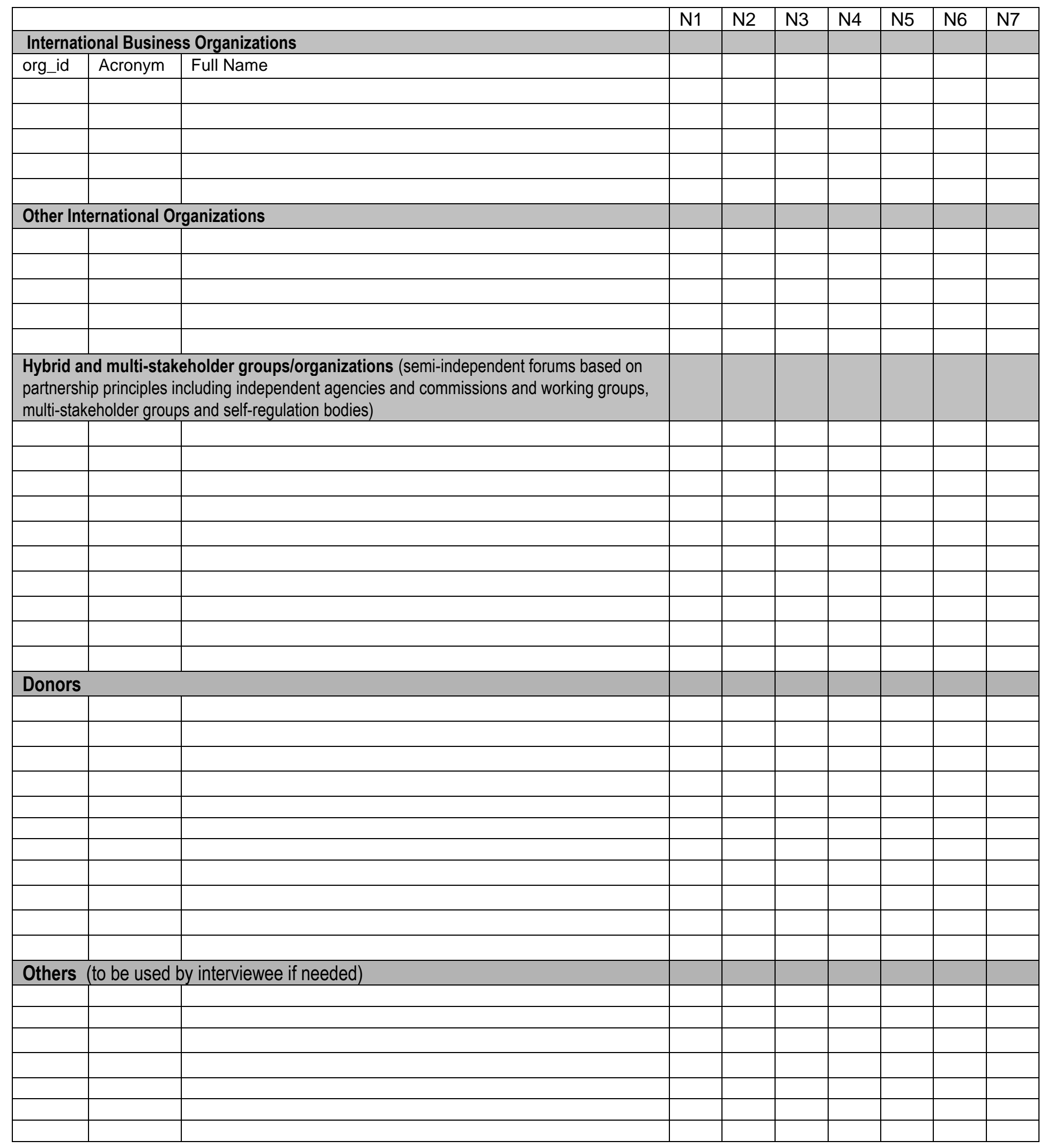

REDD Policy Formation Processes 


\section{National policy decisions and policy proposals}

\{Event: TYPOLOGY OF EVENTS: policy decisions and policy proposals. The researcher will have selected up to 5 recent major policy events which were central to the national REDD policy domain actors and will have compiled the list below with the relevant information\}

Question P 1: Now I would like to ask you some questions about REDD policy proposals being discussed and recent policy decisions taken in <Country Name > these days. These proposals may have been accepted and adopted recently, or they may still be under discussion. Please read through this list and check off the policies or policy proposals in which (ORG NAME) has had any interest.

\begin{tabular}{|c|l|l|l|l|}
\hline $\begin{array}{l}\text { Event } \\
\text { code } \\
\text { no. }\end{array}$ & Check & Event name & $\begin{array}{l}\text { Proposal / } \\
\text { Decision } \\
\text { Date }\end{array}$ & Main decision/ policy proposal \\
\hline 1 & & & & \\
\hline 2 & & & & \\
\hline 3 & & & & \\
\hline 4 & & & & \\
\hline 5 & & & & \\
\hline
\end{tabular}

For each event checked, please fill out a separate National Policy Formations Process Event Answer Sheet as indicated. Make sure to fill in the information related to the correct EVENT NUMBER 


\section{Answer Sheets: National Policy Decisions \& Proposals}

\section{EVENT No: 1}

P1.1.1 Please CIRCLE how much interest your organization had in this policy formation process.
1.Very strong
2. Strong
3. Moderate
4. Little
5. Very Little
6.None

P1.1.2. What was your organization's position on this event? Was it for or against this outcome?
1. For
2. Against
3. Partly for, partly against \{only if volunteered\}

P1.1.3. Was your organization involved in the development of the policy option represented in this event?

1. Yes

2. No

P1.1.4. Thinking back to the beginning of this event, did your organization advocate an alternative policy?
1. Yes
2. No

P1.1.5. Which of the following activities was your organization involved in, and what steps did your organization undertake to try to influence the outcome of this event? Please put a tick by all that apply.

1. Formal participation in policy development

2. Informal contact with decision-makers and political actors (e.g. lobbying)

3. Mobilizing public opinion (advocacy, press releases etc.)

4. Leading or participating in protest events linked to the policy decision/proposal

5. Other, specify:

6. None

P1.1.6. Given your organization's objectives in this event, would you say that (ORG NAME) achieved

$\begin{array}{lllll}\text { 1. all of its objectives } & \text { 2. most } & \text { 3. about half } & \text { 4. a few } & \text { 5. none }\end{array}$

ADDITIONAL NOTES: 


\section{EVENT No: 2}

P1.2.1. Please CIRCLE how much interest your organization had in this policy formation process.
1.Very strong
2. Strong
3. Moderate
4. Little
5. Very Little
6.None

P1.2.2. What was your organization's position on this event? Was it for or against this outcome?

\begin{tabular}{|l|l|l|} 
1. For & 2. Against & 3. Partly for, partly against \{only if volunteered\} \\
\hline
\end{tabular}

P1.2.3. Was your organization involved in the development of the policy option represented in this event?

\begin{tabular}{l|r} 
1. Yes & 2. No
\end{tabular}

P1.2.4. Thinking back to the beginning of this event, did your organization advocate an alternative policy?

$$
\begin{array}{l|l}
\text { 1. Yes } & \text { 2. No }
\end{array}
$$

P1.2.5. Which of the following activities was your organization involved in, and what did your organization undertake to try to influence the outcome of this event? Please put a tick by all that apply.

7. Formal participation in policy development

8. Informal contacts (e.g. lobbying) with decision-makers and political actors

9. Mobilize public opinion (advocacy, press releases etc.)

10. Lead or participate in protest events linked to the policy decision/proposal

11. Other, specify:

12. None

P1.2.6. Given your organization's objectives in this event, would you say that (ORG NAME) achieved
1. all of its objectives
2. most
3. about half
4. a few
5. none

\section{ADDITIONAL NOTES:}




\section{Answer Sheet: National Policy Decisions\& Proposals}

\section{EVENT No: 3}

P1.3.1. Please CIRCLE how much interest your organization had in this policy formation process.
1.Very strong
2. Strong
3. Moderate
4. Little
5. Very Little
6.None

P1.3.2. What was your organization's position on this event? Was it for or against this outcome?

1. For

2. Against

3. Partly for, partly against \{only if volunteered\}

P1.3.3. Was your organization involved in the development of the policy option represented in this event?
1. Yes
2. No

P1.3.4. Thinking back to the beginning of this event, did your organization advocate an alternative policy?
1. Yes
2. No

P1.3.5. Which of the following activities was your organization involved in, and what did your organization undertake to try to influence the outcome of this event? Please put a tick by all that apply.

13. Formal participation in policy development

14. Informal contacts (e.g. lobbying) with decision-makers and political actors

15. Mobilize public opinion (advocacy, press releases etc.)

16. Lead or participate in protest events linked to the policy decision/proposal

17. Other, specify:

18. None

P1.3.6. Given your organization's objectives in this event, would you say that (ORG NAME) achieved

$\begin{array}{lllll}\text { 1. all of its objectives } & \text { 2. most } & \text { 3. about half } & \text { 4. a few } & \text { 5. none }\end{array}$

\section{ADDITIONAL NOTES:}




\section{EVENT No: 4}

P1.4.1. Please CIRCLE how much interest your organization had in this policy formation process.
1.Very strong
2. Strong
3. Moderate
4. Little
5. Very Little
6.None

P1.4.2. What was your organization's position on this event? Was it for or against this outcome?
1. For
2. Against
3. Partly for, partly against \{only if volunteered\}

P1.4.3. Was your organization involved in the development of the policy option represented in this event?

$$
\begin{array}{l|l}
\text { 1. Yes } & \text { 2. No }
\end{array}
$$

P1.4.4. Thinking back to the beginning of this event, did your organization advocate an alternative policy?

$$
\begin{array}{l|l}
\text { 1. Yes } & \text { 2. No }
\end{array}
$$

P1.4.5. Which of the following activities was your organization involved in, and what did your organization undertake to try to influence the outcome of this event? Please put a tick by all that apply.

19. Formal participation in policy development

20. Informal contacts (e.g. lobbying) with decision-makers and political actors

21. Mobilize public opinion (advocacy, press releases etc.)

22. Lead or participate in protest events linked to the policy decision/proposal

23. Other, specify:

24. None

P1.4.6. Given your organization's objectives in this event, would you say that (ORG NAME) achieved
1. all of its objectives
2. most
3. about half
4. a few
5. none

\section{ADDITIONAL NOTES:}




\section{EVENT No: 5}

P1.5.1. Please CIRCLE how much interest your organization had in this policy formation process.
1.Very strong
2. Strong
3. Moderate
4. Little
5. Very Little
6.None

P1.5.2. What was your organization's position on this event? Was it for or against this outcome?

1. For

2. Against

3. Partly for, partly against \{only if volunteered\}

P1.5.3. Was your organization involved in the development of the policy option represented in this event? 1. Yes 2. No

P1.5.4. Thinking back to the beginning of this event, did your organization advocate an alternative policy?
1. Yes
2. No

P1.5.5. Which of the following activities was your organization involved in, and what did your organization undertake to try to influence the outcome of this event? Please put a tick by all that apply.

25. Formal participation in policy development

26. Informal contacts (e.g. lobbying) with decision-makers and political actors

27. Mobilize public opinion (advocacy, press releases etc.)

28. Lead or participate in protest events linked to the policy decision/proposal

29. Other, specify:

30. None

P1.5.6. Given your organization's objectives in this event, would you say that (ORG NAME) achieved

1. all of its objectives

2. most

3. about half

4. a few

5. none

\section{ADDITIONAL NOTES:}




\section{REDD Policy Formation Processes}

\section{Protest Events}

\{Note: this question applies only to non-state actors. For state actors please tick the box indicating that participation in protest events does not apply to this organization in the answer sheet and leave the sheet blank\}

$\{$ The researcher will have compiled a list of up to 5 major protest events in the national REDD policy domain. The respondent can then add other events they organized or participated in.\}

\{Protest actions are defined as mass meetings, street demonstrations and other public actions or non-violent "direct action" to publicize and mobilize support for/against a policy issue related to REDD. \}

Question P 2: Now I would like to ask you to fill in the protest answer sheet. It lists relevant protests that have been held on issues that might affect REDD policies, and it should be filled in for any other recent major protest events related to REDD in which (ORGNAME) participated. Please read through the list, check off the protest actions in which (ORG NAME) participated, and for those rows fill in the required information. 
Tick the box if participation in protest events does not apply to your organization :

Protest Events Answer Sheet:

\{To be filled in by the researcher in advance are the columns $b, c, d$, e. It is very important that the description of the protest event (column b) clearly and uniquely identifies the protest event for the interviewee: be specific). The respondent will be asked to fill in columns a, $f, g$ and $h$ for those events which his/her organization has participated in.\}

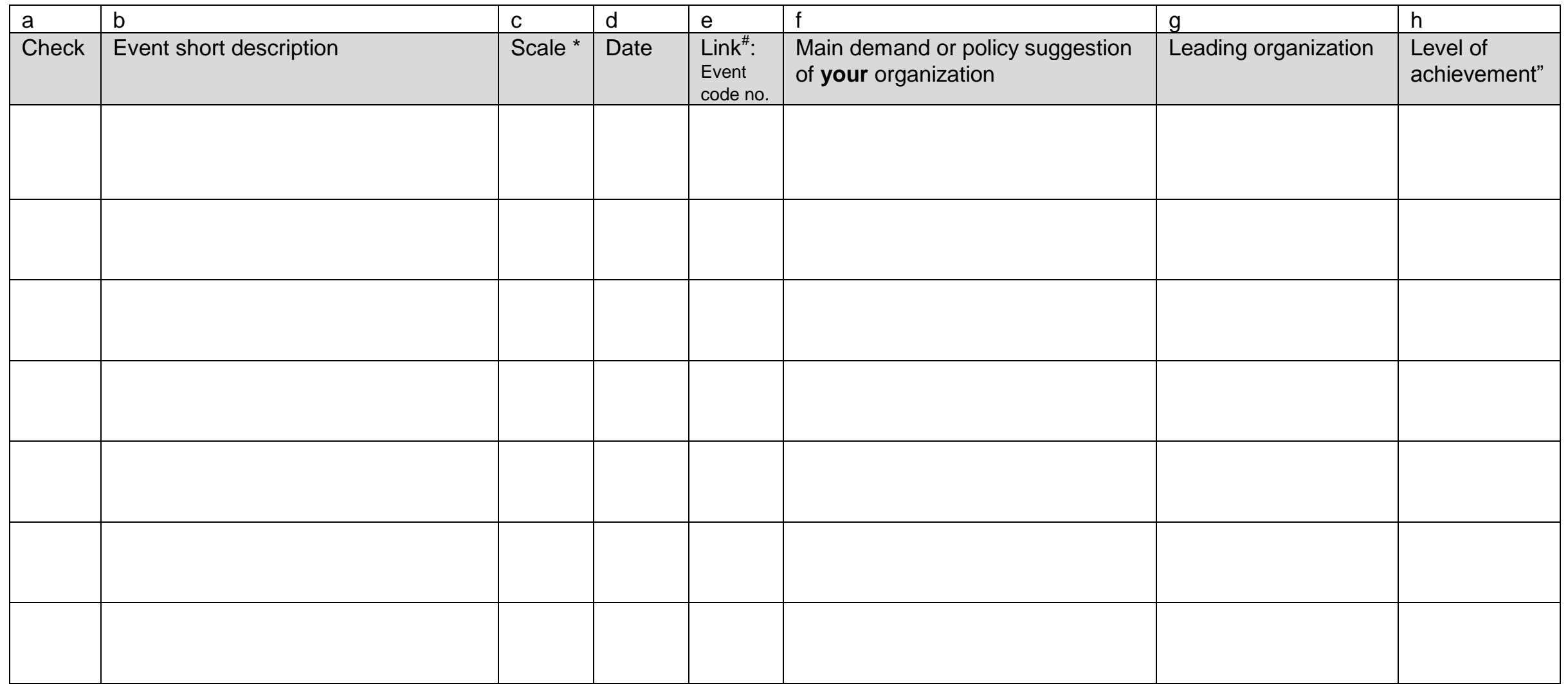

* Scale: 1. international

2. national

3. sub-national/ local

"Level of achievement: 1. all of its objectives

\# Link: if the protest event is linked to one of the above policy events, enter the event code number.

2. most

3. about half

4. a few

5. none 


\section{Organization Information}

Question O 1: To what type of organization does [ORGNAME] belong to? [enter Code]

\begin{tabular}{|c|c|c|}
\hline & Code & TYPE OF ORGANIZATION \\
\hline \multirow{4}{*}{$\begin{array}{l}\text { Governmental } \\
\text { Organization }\end{array}$} & 1 & Legislative actor: committee, body involved in policy formation, political party \\
\hline & 2 & $\begin{array}{l}\text { Executive department: ministerial/government department, body involved in } \\
\text { policy implementation }\end{array}$ \\
\hline & 3 & Independent advisory body \\
\hline & 4 & Educational / research institution \\
\hline $\begin{array}{l}\text { NGO: non-membership } \\
\text { based }\end{array}$ & 5 & Foundation/Charity/ NGO network \\
\hline \multirow{3}{*}{$\begin{array}{l}\text { NGO: membership-based } \\
\text { (individual or } \\
\text { organizations) }\end{array}$} & 6 & $\begin{array}{l}\text { Individual membership-based NGO (grass-root organization or union or } \\
\text { federation of grass-root organizations) (e.g. farmers' union, indigenous groups) }\end{array}$ \\
\hline & 7 & Professional membership-based association (e.g. journalist association) \\
\hline & 8 & Business association (e.g. plywood producer association) \\
\hline National Business & 9 & $\begin{array}{l}\text { National private business: } \\
\text { specify sector: } \ldots \ldots \ldots \ldots \ldots \ldots \ldots \ldots \ldots \ldots \ldots \ldots \ldots \ldots \ldots\end{array}$ \\
\hline \multirow{4}{*}{ International } & 10 & International NGO \\
\hline & 11 & Intergovernmental Organization (UN, World Bank....) \\
\hline & 12 & $\begin{array}{l}\text { Foreign or Multinational Business } \\
\text { specify main sector relevant to REDD: ................ }\end{array}$ \\
\hline & 13 & Foreign Government Agency \\
\hline Other & 14 & Other, specify: $\quad \ldots \ldots$ \\
\hline
\end{tabular}

Question 0 2: $\{$ Main activities of the organization in General not just related to REDD\}

Is the scope of work of the organization mainly linked to environmental issues? Tick what applies:
1. Yes

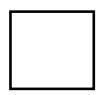
2. No

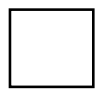

Question O 3: \{Main activities of your organization in General not just related to REDD\}

Please indicate the 3 main activities that your organization is engaged in overall (not just in relation to REDD) and indicate the amount of effort your organization typically devotes to each activity.

\begin{tabular}{|l|l|l|}
\hline & \multicolumn{2}{|c|}{ Tick which applies: } \\
\hline Main Activity: & Minor effort & Major effort \\
\hline 1. & & \\
\hline 2. & & \\
\hline 3. & & \\
\hline
\end{tabular}

Question O 4: Please briefly state up to three main current proposals of (ORGNAME) related to national policies on REDD in order of importance:

1. Most important:

2. Second:

3. Third: 
Question O 5: \{Year\}

In which year was your organization established?:

[enter year]

If year of foundation is not known:

Question 0 6: Has organization existed for more than 10 years? Tick what applies:

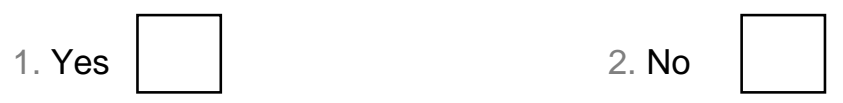

Question O 7: \{Human Resources\}

How many (full-time equivalent) paid staff does your organization employ?

FTEs [enter number]

Question O 8: \{Orientation\}

What is the main orientation of your organization? (Tick only one)

1. Local issues

2. National issues

3. International issues

\section{Question O 9: \{Membership\}}

How many (individuals) or (organizations) are members of (ORG NAME)?

If (ORG NAME) is NOT a membership organization please tick here:

If (ORG NAME) is a membership organization enter the number of individual members and/or organizational members:

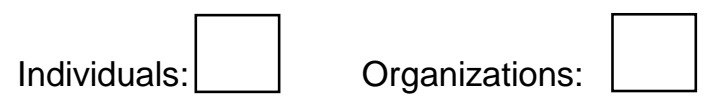

Question O 10: \{Financial Resources \}:

Within which of these broad categories does the annual budget (salaries and operating expenses) of (ORG NAME) fall into (in US\$)? Tick which one applies.

\begin{tabular}{|l|l|l|}
\hline & & Tick \\
\hline 1. & $0-1,000$ US \$ & \\
\hline 2. & $1,000-9,999$ US \$ & \\
\hline 3. & $10,000-99,999$ US \$ & \\
\hline 4. & $100,000-499,999$ US \$ & \\
\hline 5. & More than 500,000 US \$ & \\
\hline
\end{tabular}

Question 0 11: Can you split the budget according to the source of revenues?: [enter approximate \% in the column]

\begin{tabular}{|l|l|l|}
\hline SOURCE OF REVENUE & $\%$ \\
\hline \multirow{4}{*}{ International } & 1. Grants from Intergovernmental Organizations (World Bank, UN..) & \\
\cline { 2 - 3 } & 2. Grants from foreign governments (e.g. DFID, Norad...) & \\
\hline & 3. Contributions from international NGOs & \\
\hline & 4. Contributions from international private corporation /transnational corp. & \\
\hline \multirow{5}{*}{ 5ational } & 5. Budget allocation or grant from national government & \\
\cline { 2 - 3 } & 6. Contributions from domestic NGOs & \\
\cline { 2 - 3 } & 7. Contributions from domestic private corporations & \\
\cline { 2 - 3 } & 8. Membership fees & $100 \%$ \\
\hline & 9. Fees - for services (subscriptions, publications, consultancies) \\
\hline
\end{tabular}


\{Question 012 applies ONLY to non- state actors\}:

Question O 12: \{Participation in policy formation\}

Has a person of (ORGNAME) ever served in a formal advisory role in a formal government/legislatives decision-making process on climate change policies including the development of a national REDD strategy?
1. Yes
$\square$
2. No.
$\square$ 


\section{Organizational Actors Semi-Structured Interviews \\ Level 4 CODING}

Semi-structured interviews of the core organization/actors respondents will complement the Social Organization survey, they will be administered to a high ranking representative of the organization who is politically-knowledgable about REDD policy debates.

Interview might be conducts will all core organization that are part of the policy domain, or a subset of peak organizations with a balanced representation among government, business, civil society and international actors.

These interviews will provide more depth and details with regard to main the stances, and preferred policy options of the organization. The semi-structured interviews guide is organized in 4 sections. In the first set of questions, the respondent will be asked to describe the main beliefs, interests and activities of his/her organization in relation to the REDD debates.

In the second section, the respondent will be asked to comment about the main challenges posed by a REDD policy strategy and about the existing opportunities provided by the introduction of REDD policies. The third section asks to assess governance aspects of the consultation process leading to national REDD strategies. Finally the respondent will provide and assessment of existing REDD related policies and of likely policy directions in terms of effectiveness, cost-efficiency, equity and other co-benefits.

These interviews can be analysed with a full-fledged "grounded theory" approach using open coding technique. The teams will record and have these interviews transcribed into text form, and will then code them using NVivo (or another computer-assisted qualitative data analysis package) for the categories of thought and value judgment that the actors use, as well as the specific substantive information they mention.

\section{GUIDING QUESTIONS:}

\section{Section 1: Organizational Interest}

First, I would like to ask you about your organization's main interest and activities

\section{Question 1}

What is the main mandate or mission of your organization?

\section{Question 2}

When did your organization first get involved in the REDD debate and why?

\section{Question 3}

What is your organization's main position on REDD and what are your main objectives in terms of policy design and implementation?

\section{Question 4}

What are the main activities in the REDD arena that your organization is engaged in?

\section{Section 2: Policy Challenges and Opportunities}

\section{Question 5}

What are the main challenges for REDD in [COUNTRYNAME]? 


\section{Question 6 (Governance)}

In particular, are there, and if so which are the main governance challenges that need to be overcome to design and implement effective REDD policies in [COUNTRYNAME]?

(Probe on aspects related to coordination, transparency and accountability of policy actors, institutional and civil society capacity)

\section{Question 7}

Do you believe there are important opportunities that REDD can provide to [COUNTRYNAME]. If so, what are these opportunities?

\section{Question 8}

What do you think will be the consequences of the introduction of a national REDD policy strategy for [COUNTRYNAME]?

\section{Section 3: Consultation Process}

With respect to consultation processes undertaken so far for the development of the national REDD strategy....

\section{Question 9}

Can you please comment of the role, nature and effectiveness of these consultation processes?

(Probe on access to information, inclusiveness of stakeholder participation, quality of participation)

\section{Question 10}

Do you feel the position and claims of your organization were seriously considered in the decisionmaking process?

\section{Section 4: Policy assessment and 3 Es}

\section{Question 11}

Looking at existing REDD related policies and likely directions of policy design and implementation. Do you think these policies will effectively address the drivers of deforestation and degradation? Will they be effective in reducing national level carbon emission from REDD-Plus related sectors?

\section{Question 12}

So far, do you think proposed policies effectively address issue of cost-efficiency in the design and implementation of REDD related? Can you give examples on why this is the case?

\section{Question 13}

Can you comment on the extent to which equity (fairness) issues are or will be taken into account in design and implementation?

(Probe on the extent to which co-benefits - as poverty alleviation, protection of biodiversity and other environmental services, and governance improvements - will/should be included as objectives) 